\title{
Analisis Sistem Informasi Eksekutif Menggunakan User Experience Questionnaire (UEQ)
}

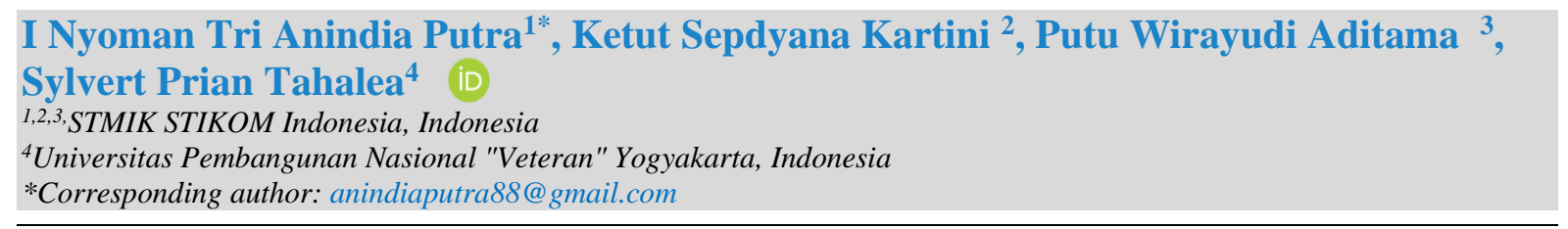

\begin{abstract}
Abstrak
Sistem informasi eksekutif merupakan salah satu sistem yang digunakan untuk menganalisa masalah yang ada dalam suatu organisasi, serta memfasilitasi kebutuhan informasi yang berkaitan dengan pemenuhan tujuan organisasi. Namun pada penggunaan SIE belum terdapat analisi kajian yang membahas mengenai tingkat kepuasan user terhadap sistem yang digunakan. Sehingga tujuan dari penelitian ini adalah untuk memberbaiki sistem yang ada serta meningkatkan kepuasan user terhadap sistem informasi. Penelitia ini menggunakan jenis penelitian deskriptif dengan jumlah populasi sebanyak 28 orang. Teknik sampling yang digunakan dalam penelitian ini adalah teknik teknik sampling jenuh, yakni menggunakan seluruh populasi sebagai sampel penelitian. Metode pengumpulan data dalam penelitian ini yang digunakan dalam penelitian ini yakni metode dilakukan dengan menggunakan metode User Experience Questionaire (UEQ), dengan tahapan pengumpulan data yang terdiri dari tahapan merancang konsep dan kajian pustaka, identifikasi masalah, pengumpulan data, analisis data dan menarik kesimpulan. Hasil dalam penelitian ini menunjukkan bahwa analisis hasil pengujian sistem informasi eksekutif dengan menggunakan metode User Experience Questionnaire memperoleh dua parameter yang dengan nilai Above Average yaitu stimulasi dan kebaruan, sehingga perlu dilakukan pengembangan penyegaran user interface terhadap sistem informasi eksekutif tersebut.
\end{abstract}

Keywords: Kuesioner Pengalaman Pengguna, Sistem Informasi, Analisis

\section{Abstract}

Executive information system is one of the systems used to analyze existing problems in an organization, as well as facilitate information needs related to the fulfillment of organizational goals. However, in the use of SIE there has been no analysis of studies that discuss the level of user satisfaction with the system used. So the purpose of this research is to improve the existing system and increase user satisfaction with the information system. This research uses descriptive research with a population of 28 people. The sampling technique used in this study is a saturated sampling technique, which uses the entire population as the research sample. The data collection method in this study used in this study is the method carried out using the User Experience Questionnaire (UEQ) method, with data collection stages consisting of stages of designing concepts and literature review, problem identification, data collection, data analysis and drawing conclusions. The results in this study indicate that the analysis of the results of testing the executive information system using the User Experience Questionnaire method obtains two parameters with an Above Average value, namely stimulation and novelty, so it is necessary to develop a refresher user interface for the executive information system.

Keywords: User Experience Questionnaire, Information System, Analysis

\section{Introduction}

Sistem informasi eksekutif berasal dari kata sistem informasi yang berarti bahwa sekumpulan komponen yang saling berhubungan, mengumpulkan, memproses, menyimpan, dan mendistribusikan informasi untuk menunjang pengambilan keputusan dan pengawasan (Puspitorini et al., 2019). Sistem informasi memberikan nilai tambah terhadap proses, produksi, kualitas, manajemen, pengambilan keputusan, dan pemecahan masalah serta keunggulan kompetitif yang tentu saja sangat berguna bagi kegiatan bisnis (Pradana, 2016). Sehingga berdasarkan pengertian sistem informasi tersebut dapat disimpulkan bahwa sistem

$\begin{array}{ll}\text { History: } & \\ \text { Received } & : 14 \text { Oktober } 2020 \\ \text { Revised } & : \text { 09 November } 2020 \\ \text { Accepted } & : 06 \text { Maret } 2021 \\ \text { Published } & : 25 \text { April } 2021\end{array}$


informasi eksekutif merupakan suatu komputasi yang banyak digunakan oleh eksekutif dalam sebuah organisasi, SIE ini cenderung digunakan untuk menganalisa masalah serta mendeteksi adanya suatu indikator penting dalam manajemen sistem sehingga mampu memfasilitasi kebutuhan informasi yang berkaitan dengan pemenuhan tujuan organisasi (Prasetyo et al., 2012; Purwanto et al., 2020). Sistem informasi eksekutif memberikan kemudahan bagi para eksekutif untuk menentukan sebuah keputusan berdasarkan data laporan penunjang yang telah disimpan sebelumnya dalam bentuk laporan berupa grafik atau tabel (Putra \& Kartini, 2019).

Dalam membangun suatu sistem informasi eksekutif dibutuhkan beberapa konsep dasar yang memungkinkan para eksekutif dapat memantau kinerja perusahaan beserta anak buahnya (Guntari et al., 2019). Konsep dasar pada sistem informasi eksekutif dibagi menjadi 3 konsep dasar yang terdiri dari faktor penentu keberhasilan atau critical success factor (CSF), management by exception (MBE) yang menampilkan perbandingan antara kinerja yang direncanakan dengan kinerja aktual, dan model mental yang memungkinkan seseorang membuat penilaian dan perkiraan untuk memahami, memutuskan tindakan yang perlu diambil dan untuk mengembalikan pelaksanaannya (Subekti et al., 2011; Sulistyo et al., 2020). Sistem Informasi Eksekutif pada STMIK STIKOM Indonesia merupakan salah satu sistem yang dibuat dengan menggunakan metode SDLC, dan sistem informasi yang sudah berjalan dan diimplementasikan sejak tahun 2018 ini belum pernah sekalipun dilakukan analisis untuk mengetahui kepuasan dari pengguna yang menggunakan sistem tersebut. Berdasarkan wawancara terhadap admin selaku pengguna sistem informasi eksekutif menyatakan bahwa ingin mengembangkan sistem informasi eksekutif menjadi lebih baik lagi. Pengembangan sistem informasi eksekutif serta analisis terhadap program SIE yang telah dikembangkan sangatlah dibutuhkan oleh suatu instansi, hal ini dikarenakan apabila tatacara pengembangan dan pengelolaannya hanya sebatas untuk melayani kebutuhan eksekutif saja tanpa prosedur yang benar, akan menimbulkan ketidakpuasan bagi pengguna SIE itu sendiri (Fatoni et al., 2019).

Salah satu upaya yang dapat dilakukan untuk mengetahui tingkat kepuasan pengguna terhadap program SIE yang dirancang yakni dengan memberikan User Experience Questionnaire (UEQ) kepada para pengguna atau user SIE. User Experience Questionnaire (UEQ) merupakan salah satu alat atau bisa disebut sebagai kuesioner yang mudah dan efisien digunakan untuk mengetahui user experience (UX) (Putro et al., 2019). UEQ ini memudahkan pengembang dalam mengetahui UX dari desain suatu sistem informasi. UEQ sendiri terdiri dari enam skala penilaian yaitu 1) attractiveness atau daya tarik yang bertujuan untuk mengetahui daya tarik suatu produk, 2) kejelasan atau perspicuity kemudahan dalam menggunakan suatu sistem, 3) efficiency yang bertujuan untuk mengetahui kemudahan pengguna dalam menyelesaikan tugas dengan sistem, 4) ketepatan atau Dependability yaitu pengguna merasa terkendali dalam berinteraksi dengan sistem, 5) stimulasi atau stimulation sistem mampu menarik dan memotivasi pengguna, dan 6) kebaharuan atau novelty yaitu sistem memiliki kreatifitas yang baru dan inovasi yang baru atau tidak (Santoso et al., 2016; Sari et al., 2021).

Penelitian mengenai pengguna User Experience Questionnaire (UEQ) untuk mengetahui kualitas sistem atau respon user terhadap sistem yang dikembangkan telah dilakukan oleh beberapa penelitian sebelumnya seperti penelitian yang dilakukan oleh (Juniantari \& Putra, 2021) mengenai "Analisis Sistem Informasi DPMPTSP Menggunakan Metode User DPMPTSP Information System Analysis Using The User Experience" yang menunjukkan hasil bahwa pada diagram benchmark menunjukkan kategori (good), (excellent), (above average) yang berarti situs memiliki kegunaan baik tetapi perlu ditingkatkan dalam kejelasan (perspicuity) untuk dapat dengan mudah dipahami oleh 
pengguna. Serta penelitian yang dilakukan oleh (Saputra et al., 2021) mengenai "Analisis Dan Evaluasi Pengalaman Pengguna Patik Bali Dengan Metode User Experience Questionnaire ( UEQ )" yang menunjukkan hasil bahwa dengan menggunakan UEQ menunjukkan user experience dari pengguna PaTik Bali dapat dikatakan baik dengan nilai rata-rata diatas 1. Hal yang membedakan penelitian mengenai "Analisis Sistem Informasi Eksekutif Menggunakan User Experience Questionnaire (UEQ)" dengan penelitian sebelumnya yakni pada penelitian kali ini dilakukan analisis terhadap sistem informasi eksekutif (SIE) yang belum pernah dilaksanakan sebelumnya dengan tujuan untuk meningkatkan kepuasan user terhadap sistem informasi.

\section{Materials and Methods}

Penelitian mengenai analisis sistem informasi eksekutif menggunakan user experience questionnaire (ueq) merupakan jenis penelitian deskriptif. Penelitian deskriptif merupakan salah satu jenis penelitian yang dimana hasil penelitian disajikan dalam bentuk deskripsi dengan didukung oleh teori dan fakta yang ada. Populasi dalam penelitian ini yakni sebanyak 28 responden pengguna sistem informasi, penarikan sampel penelitian dilakukan dengan teknik sampling jenuh, yakni menggunakan seluruh populasi sebagai sampel penelitian. Pengumpulan data dalam penelitian dilakukan dengan menggunakan metode user experience questionnaire (UEQ) yang terdiri atas 26 komponen pertanyaan yang telah tervalidasi dan memiliki tujuh (7) buah jawaban yang harus diisi oleh responden. dalam bahasa aslinya UEQ ini adalah bahasa inggris. namun sudah terdapat penelitian yang membuat UEQ tersebut dirubah kedalam bahasa indonesia(Santoso et al., 2016).

Penelitian ini terdiri dari 5 tahapan penelitian yang terdiri dari: 1) tahapan merancang konsep dan kajian pustaka yang bertujuan untuk memahami metode yang akan digunakan, 2) melakukan identifikasi masalah terkait sistem informasi yang akan dianalisis guna dikembangkan lebih lanjut, 3) pengumpulan data dengan studi kajian pustaka atau literature, menyebarkan kuisioner dengan memberikan pertanyaan dalam metode UEQ kepada 28 responden pengguna sistem informasi, 4) melakukan analisis terhadap data yang telah didapatkan dan 5) menarik kesimpulan atas analisis yang telah dilakukan dengan menggunakan metode UEQ.

\section{Results and Discussion}

Pada penelitian ini proses perhitungan User Experience Questionnaire dengan menggunakan tools yang telah tervalidasi pada penelitian (Santoso et al., 2016). Sehingga siap digunakan dan memperoleh hasil yang memiliki keakuratan yang sangat baik. Adapun hasil yang diperoleh pada penelitian ini yaitu dapat dilihat pada Gambar 1.

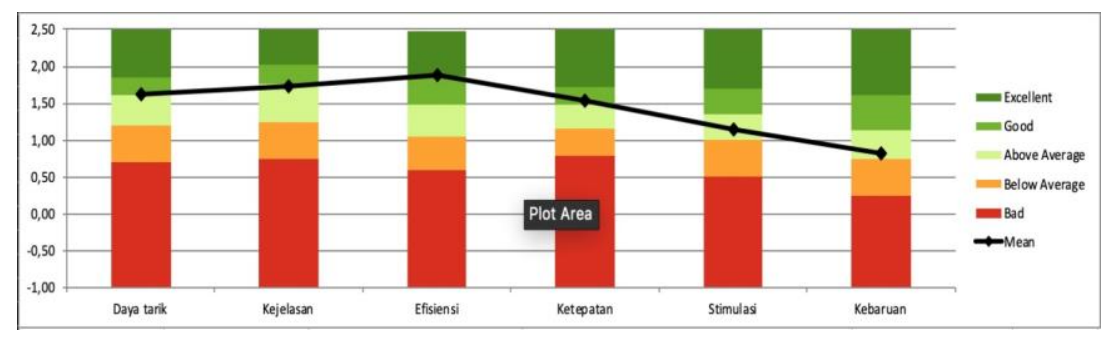

Gambar 1. Tampilan Hasil Analisis Data UEQ

Pada gambar 4 diperoleh hasil dari analisis menggunakan User Experience Quesionnaire masing masing yaitu daya tarik memperoleh peringkat Good, Kejelasan memperoleh peringkat Good, efisiensi memperoleh peringkat Excellent, ketepatan 
memperoleh peringkat good stimulasi memperoleh peringkat above average dan kebaruan memperoleh peringkat above average. Selanjutnya berdasarkan hasil yang telah diperoleh terdapat dua parameter yang perlu adanya pengembangan yaitu parameter stimulasi dan juga kebaharuan dari sistem informasi tentunya pada aspek user interface. Kedua aspek tersebut memperoleh peringkat Above Average dimana perlu dilakukan pembaharuan terkait desain user interface pada sistem informasi eksekutif STMIK STIKOM Indonesia. Sehingga mampu memberikan penyegaran dalam menggunakan sistem informasi tersebut.

Pengembangan keterbaharuan serta pengembangan stimulasi terhadap sistem informasi eksekutif STMIK STIKOM Indonesia dibutuhkan untuk meningkatkan kenyamanan pada saat penggunaan sistem. Seperti yang telah dijelaskan sebelumnya bahwa sistem informasi eksekutif yang baik adalah sistema informasi yang dapat dapat membantu para eksekutif dalam mengambil keputusan untuk kebutuhan bisnis organisasi secara tepat, akurat, dan cepat sesuai dengan fakta dan data yang ada (Subekti et al., 2011).

\section{Conclusion}

Berdasarkan Analisis hasil pengujian sistem informasi eksekutif STMIK STIKOM Indonesia dengan menggunakan metode User Experience Questionnaire memperoleh dua parameter yang dengan nilai Above Average yaitu stimulasi dan kebaruan, sehingga perlu dilakukan pengembangan penyegaran user interface terhadap sistem informasi eksekutif pada STMIK STIKOM Indonesia.

\section{References}

Fatoni, Supratman, E., \& Antoni, D. (2019). Kerangka Kerja Sistem Informasi Eksekutif Perguruan Tinggi. Jurnal Teknologi Informasi Dan Ilmu Komputer (JTIIK), 6(3), 257-266. https://doi.org/10.25126/jtiik.20196946.

Guntari, ella wahyu, Permana, aldi sidik, \& Umbara, fajri rakhmat. (2019). Prototype Sistem Informasi Eksekutif Dosen di Perguruan Tinggi Swasta ABCD. Jurnal Masyarakat Informatika Unjani, 3(2), 53-61. https://doi.org/10.26874/jumanji.v3i02.65.

Juniantari, \& Putra, nyoman T. . (2021). Analisis Sistem Informasi Dpmptsp Menggunakan Metode User Dpmptsp Information System Analysis Using The User Experience. Jurnal Informatika Dan Komputer, 4(1), 31-37. https://doi.org/10.33387/jiko.

Pradana, M. (2016). Perencanaan skema sistem informasi untuk aktivitas manajemen. Jurnal Ekonomi Dan Bisnis, 4(1), 65-71. https://doi.org/10.37676/ekombis.v4i1.155.

Prasetyo, E., Nugroho, L. E., \& Aji, M. N. (2012). Perancangan Data Warehouse Sistem Informasi Eksekutif untuk Data Akademik Program Studi. Jurnal Inasional Teknik Elektro Dan Teknologi Informasi, 1(3). https://doi.org/10.22146/jnteti.v1i3.122.

Purwanto, A., Hanief, S., \& Nugroho, A. (2020). Perancangan sistem informasi eksekutif berbasis web pada upt laboratorium hayati pertanian bali untuk penentuan penyakit pada bibit tanaman. Jurnal Teknologi Informasi Dan Komputer, 6(2). https://doi.org/ 10.36002/jutik.v6i2.1054.

Puspitorini, S., Astuti, R. W., \& Hakim, F. Al. (2019). Sistem informasi eksekutif manajemen data kinerja dosen prodi teknik informatika stmik nurdin hamzah. Jurnal Sebatik, 23(2), 624-632. https://jurnal.wicida.ac.id/index.php/sebatik/article/view/819.

Putra, nyoman tri anindia, \& Kartini, ketut sepdyan. (2019). Rancang Bangun Sistem Informasi Eksekutif pada STMIK STIKOM Indonesia. International Journal of Natural Science Dan Engineering, 3(3), 122-129. https://doi.org/ 10.23887/ijnse.v3i3.24147.

Putro, S., Kusrini, \& Kurniawan, M. P. (2019). Penerapan Metode UEQ dan Cooperative 
Evaluation untuk Mengevaluasi User Experience Lapor Bantul. Creative Information Technology Journal, 6(1), 27-37. https://doi.org/10.24076/citec.2019v6i1.242.

Santoso, H. B., Schrepp, M., Yugo Kartono Isal, R., Utomo, A. Y., \& Priyogi, B. (2016). Measuring user experience of the student-centered E-learning environment. Journal of Educators Online, 13(1), 1-79.

Saputra, I. N., Wijaya, W., Santika, P. P., Bagus, I., Indra, A., \& Alit, I. N. (2021). Analisis Dan Evaluasi Pengalaman Pengguna Patik Bali Dengan Metode User Experience Questionnaire ( UEQ). Jurnal Teknologi Informasi Dan Ilmu Komputer (JTIIK), 8(2). https://doi.org/10.25126/jtiik.202182763.

Sari, Y., Arafah, M., \& Novitasari. (2021). Evaluasi Usability Sistem Informasi Akademik Dosen Menggunakan User. Jurnal Resti ((Rekayasa Sistem Dan Teknologi Informasi), 1(10), 247-253. https://doi.org/10.29207/resti.v5i2.3022.

Subekti, M., Widjaya, R. B. R. D., Heriyanni, E., \& Dewi, G. (2011). Analisis Dan Perancangan Sistem Informasi Eksekutif Pemasaran Pada Distributor Alat Tulis Kantor: Studi Kasus Pada Benza Prima. Comtech: Computer, Mathematics And Engineering Applications, 2(2), 955-967. https://doi.org/https://doi.org/10.21512/comtech.v2i2.2847.

Sulistyo, F., Andryana, S., \& Winarsih. (2020). Sistem Informasi Eksekutif Fakultas Teknologi Komunikasi dan Informatika Universitas Nasional. Jurnal Media Informatika Budidarma, 4(2019), 544-551. https://doi.org/10.30865/mib.v4i3.2137. 